\title{
Isolation of a diaminobutyric acid-degrading bacterium from the sheep rumen ${ }^{* 1}$
}

\author{
H. Peng ${ }^{1}$, D. Revell ${ }^{2}$ and J.D. Brooker ${ }^{3}$ \\ ${ }^{1}$ Adisseo Life Science (Shanghai) Co., Ltd. \\ Shanghai 200122, P.R. China \\ ${ }^{2}$ CSIRO Livestock Industries 3, WA 6014, Australia 3 \\ ${ }^{3} J K$ Consulting, United Kingdom
}

\begin{abstract}
Anti-nutritional factors such as non-protein amino acids (NPAAs) have been found in some plants. However, the utilization of these plants as animal feed is limited due to the presence of NPAA and neurotoxin such as diaminobutyric acid (DABA). A bacterium which was capable of degrading DABA was isolated from the sheep rumen. In vitro studies showed that the bacterium could use DABA as a nitrogen source and required a carbon source such as glucose for its growth. The degradation ranged from 3.2 to $83.5 \%$ depending on the levels of glucose and DABA in the medium and incubation periods.
\end{abstract}

KEY WORDS: non-protein amino acids, diaminobutyric acid, sheep rumen, rumen bacteria

\section{INTRODUCTION}

Neurological disorders, and even death, have been observed from sheep consuming Lathyrus sylvestris hay containing diaminobutyric acid (DABA) (Rasmussen et al., 1993). In sheep feeding trials with Acacia angustissima, similar symptoms have been observed, with some sheep dying within 9 days of introducing the feed (Odenyo et al., 1997). Evans et al. (1985) reported the presence of nonprotein amino acids (NPAAs), $4-N$-acetyl-2,4-diaminobutyric acid (ADBA) and 2,4-diaminobutyric acid (DABA), in the seeds of A. angustissima. Therefore,

\footnotetext{
* Supported by the Australian Centre for International Agricultural Research (ACIAR) and the International Postgraduate Research Scholarship provided by the University of Adelaide, Australia

${ }^{3}$ Corresponding author: e-mail: jd.brooker@yahoo.co.uk
} 
the NPAAs contained in A. angustissima may be responsible for neurotoxicity in sheep. Rasmussen et al. (1993) also found that the toxicity of L. sylvestris was reduced when sheep were allowed to adapt to the diet by slowly increasing the level of hay on offer. This adaptation involved the rumen microflora, as demonstrated by exchange of rumen contents between adapted sheep and sheep fed lucerne (Rasmussen et al., 1993) where ruminal contents from adapted sheep prevented toxicity in native animals and sheep adapted to L. sylvestris showed symptoms of toxicity after receiving rumen contents from sheep fed lucerne. A reduction in toxicity has also been shown when sheep were adapted to consuming A. angustissima (Odenyo et al., 1997).

Therefore adaptation to ADBA or DABA-containing forage may induce selection for toxin-degrading bacteria. It is hypothesized that DABA-degrading bacteria could be isolated through enrichment using $A$. angustissima leaves as a substrate.

\section{MATERIAL AND METHODS}

\section{Enrichment and isolation of DABA-degrading bacteria}

Rumen fluid was freshly collected from a sheep fed a lucerne-based diet. After collection, the sample was immediately transferred to a COY anaerobic hood. 100 $\mu 1$ of the rumen fluid was inoculated into a Hungate tube containing $5 \mathrm{ml}$ of NB medium (Nili and Brooker, 1995; no carbon or nitrogen source) supplemented with $1.0 \mathrm{~g}$ of finely ground $A$. angustissima leaves. The culture was incubated at $39^{\circ} \mathrm{C}$. After 7 days continuous subculture, bacteria were isolated from the final enrichment culture by plating onto $\mathrm{mBHI}$ plates under anaerobic conditions. A single colony from each isolate was inoculated into $\mathrm{mBHI}$ broth (Brooker et al., 1995) and the purity of cultures was checked by light microscopy.

\section{DABA degradation under anaerobic conditions}

The bacterial isolate with the highest DABA-degrading capacity was inoculated into $1 \mathrm{ml}$ of NB medium containing 2 levels of DABA and 3 levels of glucose $(0$, 0.2 and $0.4 \%$ ). DABA was the only $\mathrm{N}$ source in the medium. Medium without inoculation was used as control. After 1 day and 4 days incubation, the samples were centrifuged and the supernatants were collected for DABA analysis by the colorimetric method (Rao et al., 1964). Duplicate samples were tested for all treatments. 


\section{RESULTS}

Changes in the bacterial population were observed during the enrichment as the proportion of rods in the medium was considerably enriched compared with cocci. One of the isolates was rod-shaped and was temporarily named as R3.

DABA degradation by R3 at two DABA concentrations was significantly increased by the addition of two different concentrations of glucose after 1 and 4 days anaerobic incubation; the control was without glucose (Table 1). DABA degradation was significantly greater at $0.4 \% \mathrm{w} / \mathrm{v}$ glucose than $0.2 \% \mathrm{w} / \mathrm{v}$ glucose for each of the DABA concentrations and incubation periods tested $(\mathrm{P}<0.05)$. Only very limited degradation of DABA was observed after 1 or 4 days incubation (5.8 and $7.8 \mu \mathrm{g} / \mathrm{ml}$ ) by R3 in medium without glucose was observed.

Table 1. Effects of different concentrations of DABA and glucose on DABA degradation by R3 after 1 or 4 days incubation under anaerobic conditions

\begin{tabular}{cccccc}
\hline $\begin{array}{l}\text { Incubation } \\
\text { period day(s) }\end{array}$ & $\begin{array}{c}\text { Glucose } \\
\%\end{array}$ & $\begin{array}{c}\text { DABA conc. } \\
\text { control, } \mu \mathrm{g} / \mathrm{ml}\end{array}$ & $\begin{array}{c}\text { DABA conc. R3, } \\
\mathrm{g} / \mathrm{ml}\end{array}$ & $\begin{array}{c}\text { DABA } \\
\text { degraded, } \mu \mathrm{g} / \mathrm{ml}\end{array}$ & $\begin{array}{c}\text { Degraded } \\
\%\end{array}$ \\
\hline 1 & 0.0 & $87.5 \pm 1.46^{1}$ & $84.7 \pm 0.49$ & $2.8^{\mathrm{a}}$ & 3.2 \\
& 0.2 & & $42.9 \pm 0.48$ & $44.6^{\mathrm{b}}$ & 50.9 \\
& 0.4 & & $36.2 \pm 0.49$ & $51.3^{\mathrm{c}}$ & 58.7 \\
& 0.0 & $195.9 \pm 4.36$ & $179.9 \pm 0.91$ & $16.0^{\mathrm{a}}$ & 8.2 \\
& 0.2 & & $144.1 \pm 0.97$ & $51.8^{\mathrm{b}}$ & 26.4 \\
& 0.4 & & $136.4 \pm 1.94$ & $59.5^{\mathrm{c}}$ & 30.4 \\
& 0.0 & $84.1 \pm 0.97$ & $76.3 \pm 1.94$ & $7.8^{\mathrm{a}}$ & 9.2 \\
& 0.2 & & $27.9 \pm 0.97$ & $56.2^{\mathrm{b}}$ & 66.8 \\
& 0.4 & & $13.9 \pm 1.44$ & $70.2^{\mathrm{c}}$ & 83.5 \\
& 0.0 & $194.9 \pm 1.45$ & $164.9 \pm 1.46$ & $30.0^{\mathrm{a}}$ & 15.4 \\
& 0.2 & & $118.9 \pm 0.97$ & $76.0^{\mathrm{b}}$ & 39.0 \\
& 0.4 & & $99.1 \pm 0.49$ & $95.8^{\mathrm{c}}$ & 49.2 \\
\hline
\end{tabular}

${ }^{1}$ mean \pm standard error mean of 2 replications

2 within each DABA concentration at each incubation period, values of DABA degraded with different superscripts differ significantly at $\mathrm{P}<0.05$

After overnight anaerobic incubation, the total bacterial viable count of R3 was significantly increased (around 20 times) with the addition of glucose to the medium $(\mathrm{P}<0.05)$ (Table 2$)$. This increase in total viable counts also corresponded with a significant increase in DABA degradation $(\mathrm{P}<0.05)$. The total viable count $\left(0.5 \times 10^{7} \mathrm{cfu} / \mathrm{ml}\right)$ and DABA degradation by $\mathrm{R} 3$ in medium without glucose at two different DABA concentrations was very limited (5.3 and $1.0 \mu \mathrm{g} / \mathrm{ml}$, respectively). No significant differences were found in total viable count of R3 or DABA degradation between medium containing either 0.2 or $0.6 \% \mathrm{w} / \mathrm{v}$ glucose. 
Table 2. Effect of different concentrations of DABA and glucose on viable bacterial count and DABA degradation by R3 after overnight incubation

\begin{tabular}{cccccc}
\hline $\begin{array}{c}\text { Glucose } \\
\%\end{array}$ & $\begin{array}{c}\text { DABA conc. } \\
\text { control, } \mu \mathrm{g} / \mathrm{ml}\end{array}$ & $\begin{array}{c}\text { DABA conc. } \\
\mathrm{R} 3, \mu \mathrm{g} / \mathrm{ml}\end{array}$ & $\begin{array}{c}\text { DABA } \\
\text { degraded, } \mu \mathrm{g} / \mathrm{ml}\end{array}$ & $\begin{array}{c}\text { DABA } \\
\text { degraded, } \%\end{array}$ & $\begin{array}{c}\text { Viable count } \\
\times 10^{7} \mathrm{cfu} / \mathrm{ml}\end{array}$ \\
\hline 0.0 & $86.5 \pm 0.49^{2}$ & $81.2 \pm 0.97$ & $5.3^{\mathrm{a}}$ & 6.2 & $0.5^{\mathrm{a}} \pm 0.03$ \\
0.2 & & $63.3 \pm 1.45$ & $23.2^{\mathrm{b}}$ & 26.9 & $11.7^{\mathrm{b}} \pm 0.81$ \\
0.6 & & $62.3 \pm 0.49$ & $24.2^{\mathrm{b}}$ & 28.0 & $9.9^{\mathrm{b}} \pm 0.35$ \\
0.0 & & & & & \\
0.2 & & $178.0 \pm 0.97$ & $1.0^{\mathrm{a}}$ & 0.5 & $0.5^{\mathrm{a}} \pm 0.04$ \\
0.6 & & $160.6 \pm 0.97$ & $18.4^{\mathrm{b}}$ & 10.3 & $10.4^{\mathrm{b}} \pm 0.62$ \\
\hline
\end{tabular}

${ }^{1}$ the initial bacterial number $\left(0 \mathrm{~h}\right.$ incubation) was $5.9 \pm 0.19\left(\times 10^{5}\right) \mathrm{cfu} / \mathrm{ml}$

${ }^{2}$ mean \pm standard error mean of 2 replications for DABA concentrations, mean \pm standard error mean of 3 replications for total viable counts

${ }^{\mathrm{ab}}$ within each DABA concentration, values for total viable count with different superscripts differ significantly at $\mathrm{P}<0.05$

\section{DISCUSSION}

The results have shown that DABA-degrading bacteria could be isolated from the sheep rumen after enrichment in a minimal defined medium containing A. angustissima leaves as the source of $\mathrm{N}$ and carbon. This shows that bacteria with certain characteristics can be selected from the diverse population of microorganisms present in the ruminal environment when an appropriate selection process was applied. This is supported by the studies of Rasmussen et al. (1993) and Odenyo et al. (1997) who showed that animals could develop the ability to reduce the toxicity of NPAAs, and that this was due to adaptation or selection of ruminal microflora. It has been established previously that microbial adaptations include detoxification of plant toxicants such as some alkaloids (e.g., mimosine) (Allison et al., 1990). Therefore, with the appropriate growth environment and under positive selection pressure, the population of particular bacteria can be boosted.

Free amino acids and peptides not only can be used as $\mathrm{N}$ sources by certain ruminal microorganisms, but also can be used as energy sources (Chen and Russell, 1988). The results of DABA degradation by R3 and bacterial viable count with differing levels of DABA and glucose showed that this bacterium required a carbon source other than DABA, although DABA can provide the N. Even though small amounts of DABA were degraded by R3 in the absence of glucose, the slow growth that occurred in the absence of a carbon source may indicate that the energy yield from DABA fermentation alone was not sufficient to provide an energy source for R3. This agrees with previous reports that most ruminal bacteria 
are unable to utilize amino acids and peptides as energy sources in the absence of carbohydrates because the energy yield from amino acid fermentation is very limited.

\section{CONCLUSIONS}

The results from this study showed that enrichment of specific bacteria with appropriate substrate was an effective tool to isolate bacteria from a mixed bacterial population and anti-nutritional factors in certain plants could be removed by selected rumen bacteria.

\section{REFERENCES}

Allison M.J., Hammond A.C., Jones R.A., 1990. Detection of rumen bacteria that degrade toxic dihydroxypyridine compounds produced from mimosine. Appl. Environ. Microbiol. 56, 590594

Brooker J.D., Lum D.K., Miller S., Skene I., O’Donovan L., 1995. Rumen microorganisms as providers of high quality protein. Livest. Res. Rural Develop. 6 (3)

Chen G., Russell J.B., 1988. Fermentation of peptides and amino acids by a monensin-sensitive ruminal Peptostreptococcus. Appl. Environ. Microbiol. 54, 2742-2749

Evans C.S., Clardy J., Hughes P.F., Bell E.A., 1985. 2-amino-4-acetylaminobutyic acid, 2,4diaminobutyric acid and 2-amino-6N-oxalylureidopropionic acid in seeds of Acacia angustissima. Phytochemistry 24, 2273-2275

Nili N., Brooker J.D., 1995. A defined medium for rumen bacteria and identification of strains impaired in de novo biosynthesis of certain amino acids. Lett. Appl. Microbiol. 21, 69-74

Odenyo A.A., Osujia P.O., Karanfila O., Adinewa K., 1997. Microbiological evaluation of Acacia angustissima as a protein supplement for sheep. Anim. Feed Sci. Tech. 65, 99-112

Rao S.L.N., Adhiya R.R., Sarma P.S., 1964. The isolation and characterisation of $\beta$ - $N$-oxalyl-L- $\alpha$, $\beta$-diaminoprpionic acid: a neurotoxin from the seeds of $L$. sativus. Biochemistry 3, 432-436

Rasmussen M.A., Allison M.J., Foster J.G., 1993. Flatpea intoxication in sheep and indications of ruminal adaptation. Vet. Hum. Toxicol. 35, 123-127 